\title{
RAPID IDENTIFICATION OF BOVINE ROTAVIRUS BY ELECTROPHORESIS IN AGAROSE GEL
}

\author{
I. PŠIKAL, R. DVOŘ́K, J. FRANZ, J. STTĚPÁNEK \\ Department of Virology, Veterinary Research Institute, 62132 Brno
}

Received November 1, 1990

\begin{abstract}
Pšikal I., R. Dvořák, J. Franz, J. Štěpánek: Rapid Identification of Bovine Rotavirus by Electrophoresis in Agarose Gel. Acta vet. Brno, 60, 1991: 253-261.

Horizontal electrophoresis of the rotavirus genome: in agarose (EPA), indirect immunoenzymatic analysis (ELISA) and counter-immunoelectroosmophoresis (CIEOP) were compared for the identification of rotavirus in 94 feces samples collected from scouring calves in 6 rearing premises. Positive results by all three methods were obtained in 48 animals $(51 \%)$, most effective being ELISA and EPA (both 43) and least effective CIEOP (29). The sensitivity of the rotavirus genome demonstration by EPA was equal to that of indirect ELISA (88\%), which demonstrates the group-specific rotavirus antigen. The sensitivities of EPA and ELISA were higher by $31 \%$ than that of CIEOP. Identical results of ELISA and EPA, CIEOP and EPA, and ELISA and CIEOP were obtained in 89.3, 82.9 and $80.8 \%$, respectively. Compared with ELISA and CIEOP, EPA is a straightforward procedure involving neither a complicated processing of samples, nor the preparation of a specific hyperimmune serum. The time required for EPA equals to one half and one fifth of the time necessary for ELISA and CIEOP, respectively.
\end{abstract}

Bovine rotavirus, diagnosis, electrophoresis - EPA, ELISA, CIEOP

Gastroenteral infections in calves, manifested by scours and associated with increased mortality, pose a serious problem in local cattle herds. They affect newborn calves mostly and are associated with considerable economic losses, resulting from retarded growth, impairment of the general condition and increased treatment costs and mortality.

In most cases, rotaviruses have been identified in the gut contents in many animal species and children affected with acute gastroenteritis (Bishop et al. 1973; McNulty et al. 1976). Also attempts to demonstrate rotaviruses as causative agents of gastroenteritis in calves have been reported repeatedly. For a long time, however, such attempts were limited to experimental infections and to virus propagation in cell cultures (Mebus et al. 1969, 1977; Bridger and Woode 1975). Owing to the poor adaptability of bovine rotaviruses to serial propagation in cell cultures, laborious and sophisticated procedures are necessary for this purpose and therefore rapid methods of direct and indirect detection and identification have been introduced into laboratory diagnostics. Originally, only electron and immunoelectron microscopy were used (Bridger and Woode 1975), later the techniques of counter-immunoelectroosmophoresis - CIEOP (Middleton et al. 1976), complement fixation ( $\mathrm{Z}$ issis et al. 1978), immunoenzymatic analysis - ELISA (Bidwell et al. 1977; Ellens and de Leew, 1977), radioimmunoanalysis - RIA (Sarkinen et al. 1980) and reverse passive haemagglutination and latex haemagglutination (Sanekata et al. 1981) were developed. Recently, methods based on the effects of the electric field on the rotavirus genome, extracted from clinical samples directly, have been introduced. The arrangement of the rotavirus genome, formed by segments of double-stranded RNA with molecular mass ranging between $0.2 \times 10^{6}$ and $2.0 \times 10^{6}$ (Clarke and $\mathrm{McCrae} \mathrm{1981)}$ and consequently with various migration speeds in polyacrylamide and agarose gels, results in a characteristic distribution called electrophorogramme (Pedley et al. 1983). A comparison of RNA electrophoretogrammes of rotaviruses isolated during an epidemic outbreak of scours allows to use the genome analysis not only for the aetiological diagnosis, but also for epidemiological investigations (Fijtman et al. 1987). 
The aim of our experiments was to develop and test the simplest procedures of horizontal electrophoresis in agar (EPA) for routine detection and characterization of the rotavirus RNA separated from feces collected from scouring calves.

\section{Materials and Methods}

\section{Samples and their processing:}

Feces samples, collected from scouring calves, and culture media, collected after repeated passages of rotavirus isolates in the cell lines MA 104 or MDBK, were examined for the presence of rotaviruses. The examinations were performed currently since January to May 1990, i. e. during a period when frequent scours were recorded in 3- to 14-day-old calves in 6 separated rearing premises in the South Moravian county. A total of 94 calves were examined.

1) Feces: The samples were collected into plastic bottles, frozen on dry ice immediately and transported to the laboratory. A $20 \%$ suspension was prepared in the Eppendorf test tubes containing $400 \mu \mathrm{l}$ of respective buffered solution using and adapted bacteriological loop. The composition of the buffered solutions was as follows:

a) $0.01 \mathrm{M}$ phosphate buffer $\mathrm{pH} 7.2$ for ELISA,

b) extraction buffer $\mathrm{pH} 7.4$ for EPA, consisting of $0.02 \mathrm{M}$ Tris-hydrochloride, $0.3 \mathrm{M}$ sodium chloride, $0.01 \mathrm{M}$ magnesium chloride, $0.1 \%$ sodium dodecylsulphate, $5 \mathrm{mM}$ EDTA, $4 \%$ saccharose and $0.04 \%$ bromphenol blue,

c) veronal buffer $\mathrm{pH} 8.5$ for CIEOP, consisting of $0.05 \mathrm{M}$ sodium veronal, $3 \mathrm{mM}$ citric acid and $0.3 \mathrm{mM}$ oxalic acid.

An equal part of a phenol + chloroform mixture $(1: 1)$ was added to the samples suspended in the extraction buffer and the test tubes were shaken gently for 60 seconds to obtain a homogeneous suspension before centrifugation. All suspensions were processed in the $\mathrm{K}-24$ centrifuge (Janetzki) at $8000 \mathrm{~g}$ for 10 minutes. The supernatants for ELISA and CIEOP were stored at $+4{ }^{\circ} \mathrm{C}$, while those for EPA (the aqueous phase containing the double-stranded RNA segments) were transferred into other test tubes and kept at room temperature until examined.

2) Culture media: Samples of culture media were diluted and centrifuged in the same way as the feces samples. The volume of the aqueous phase was measured and, after adding 3 parts of $96 \%$ ethanol to 1 part of the fluid, the mixture was left to precipitate at $-20^{\circ} \mathrm{C}$ overnight. After processing in the K-24 centrifuge (Janetzki) at $10000 \mathrm{~g}$ for 30 minutes, the precipitate was resuspended in $50 \mu \mathrm{l}$ of the extraction buffer and used for EPA.

Electrophoresis in agarose gel (EPA):

A modification of horizontal electrophoresis in a 5-mm-thick layer of $1.5 \%$ agarose, as described by Chudzio et al. (1989), was used. The gel was prepared by boiling agarose (Sigma) in $0.09 \mathrm{M}$ Tris-borate buffer $\mathrm{pH} 8.2$. Approx. $35 \mathrm{ml}$ of the liquid gel were poured into an adapted microtitre plate lid $8.5 \times 8 \mathrm{~cm}$, into which a comb had been placed to form starts. After solidification the comb was removed, the lid was put into an electrophoretic vessel (own design) and approx. $300 \mathrm{ml}$ of Tris-borate buffer were poured into it. $50 \mu \mathrm{l}$ of the processed sample were applied on respective start by a micropipette. The electrophoretic vessel was then connected to a voltage generator so that cathode passed the vessel on the side of the agarose layer, where the samples were applied. The reaction was left to run at $100 \mathrm{~V}$ for 1.5 hours. After switching off the voltage generator, the gel was stained in ethidiumbromide solution $\left(1 \mu \mathrm{g} \cdot \mathrm{ml}^{-1}\right)$ for 10 minutes. The stained segments were viewed under ultraviolet light at $312 \mathrm{~nm}$ (Transiluminator, UVP, Cambridge).

Enzymoimmunoanalysis :

The modification described by Bidwell et al. (1977) was used for rotavirus demonstration. The IgG fraction of rabbit antiserum to rotavirus $\left(100 \mu \mathrm{g} \cdot \mathrm{ml}^{-1}\right)$ was pipetted into each well of a microtitre plate and left there for 18 hours. After a thorough washing of the wells, $0.1 \mathrm{ml}$ of the examined suspension, $0.1 \mathrm{ml}$ of the optimal dilution of the positive calf serum to rotavirus and $0.1 \mathrm{ml}$ of a solution of swine antibody to bovine IgG, conjugated with horse-radish peroxidase ( $\mathrm{SwAB} / \mathrm{Px}$, USOL, Prague, diluted 1:2 000), were pipetted into the wells sequentially. Each step was followed by a thorough washing and each component was left in the wells for 120 minutes. Finally, $0.1 \mathrm{ml}$ of substrate (5-aminosalicylic acid $+0.005 \%$ hydrogen peroxide) was pipetted into each well. After 30 minutes, the colour reaction of the samples was compared with that of positive and negative controls. 


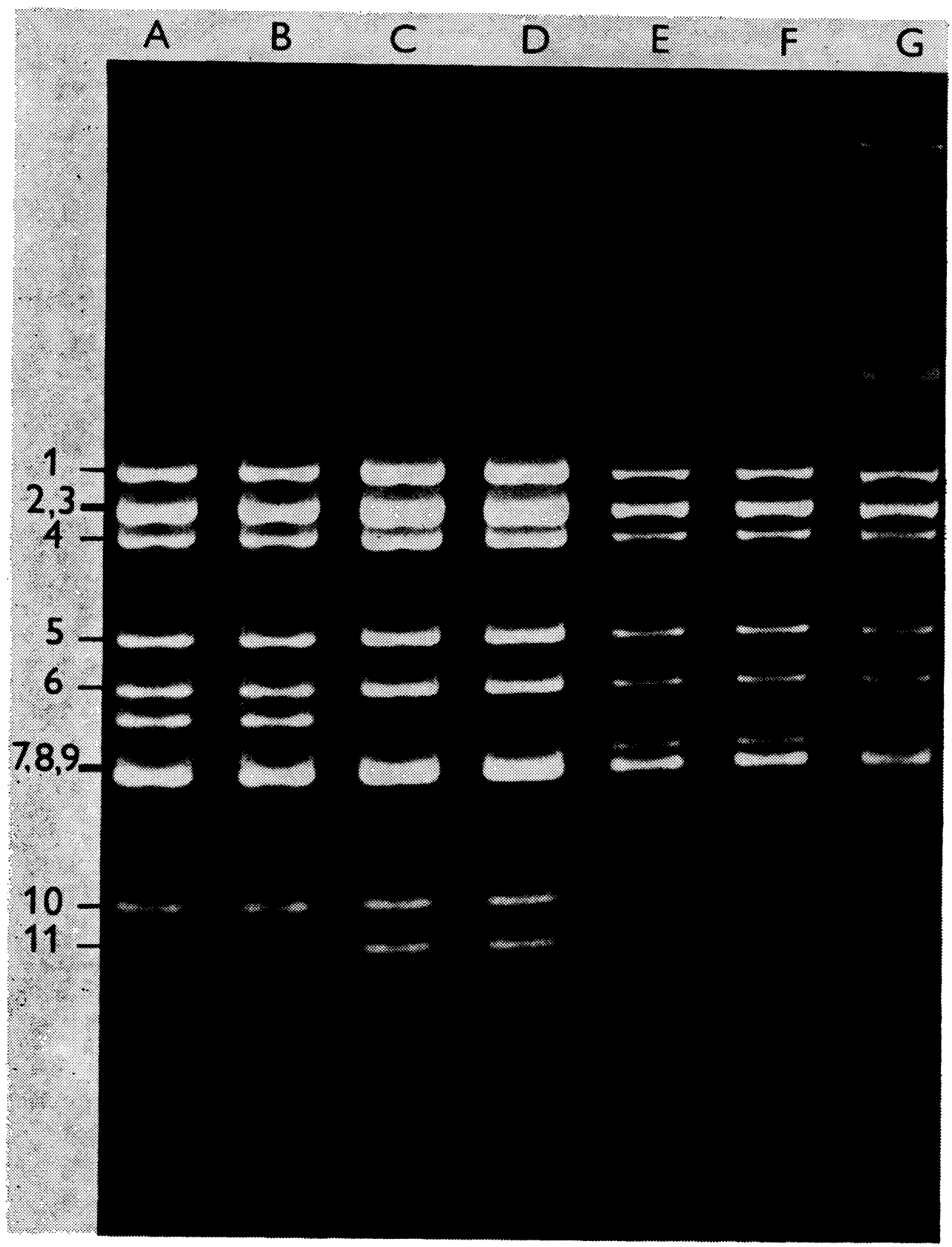

Fig. 1. Electrophoresis of rotavirus RNA, extracted from fecal = fecal samples.

Bands $A, B=$ sample TM-207, kands $C, D=$ sample TM-224, bands $E, F=$ sample TM-123, band $\mathrm{G}=$ sample $\mathrm{TM}-249$.

1 through $11=$ segment numbers 
Counter-immunoelectroosmophoresis:

The modified method, described by Dea et al. (1980), was used for the rotavirus antigen demonstration. $1 \%$ agarose gel in veronal buffer ( $\mathrm{pH} 8.5)$ was placed into an electrophoretic vessel (USOL, Prague) and the processed feces samples were applied into starting wells (diameter $4 \mathrm{~mm}$ ) on the cathodic side. The opposite fwells, at a distance of $10 \mathrm{~mm}$, were filled with rotavirus antiserum. The reaction was left to run at $150 \mathrm{~V}$ for 90 minutes. After a thorough washing of the gel in physiological saline overnight and rinsing with distilled water, the precipitation lines were visualized by a treatment with $1 \%$ tannic acid for 15 to 20 minutes.

\section{Results}

Analysis of rotavirus genome by horizontal electrophoresis in agarose

A characteristic electrophoretic distribution pattern of the rotavirus RNA segments in agarose gel was obtained from positive samples, 8 bands being discernible in most cases (Fig. 1). This was up to 3 bands less than described for the rotavirus RNA analysis in polyacrylamide gels. Despite this reduction, electrophoretic patterns differing in the migration speeds of some segments were obtained from some feces samples. Marked differences in migration speeds of the RNA segments extracted from the samples TM-207 (lanes A and B), TM-123 (lanes E and F) and TM-224 and TM-249 (lanes C, D and G) can be seen in Fig. 1. The electrophoretogrammes of the samples TM-224 and TM-249 were the most typical for the migration of the rotavirus RNA segments extracted from positive samples and correspond to the migration pattern of the genome of the rotavirus reference strain Lincoln (Fig. 2, lane D). Bovine rotavirus could be isolated and adapted for growth in the cell line MA-104 from the feces samples TM-224 and TM-207. Electrophoretic profiles of their genomes after 6 passages in the $\mathrm{MA}-104$ cells (Fig. 2, lanes $\mathrm{B}$ and $\mathrm{C}$ ) are comparable with that of the strain $B R-408$ in its 408 th passage in the cell line MDBK (Fig. 2, lanes A and E). The segment distribution of the low-passage isolates TM-207 and TM-224 did not differ from the original patterns as presented in Fig. 1. Marked differences both in the number of segments, and in the migration speed of some of them can be seen in the high-passage strain BR-408.

Negative samples were easily identifiable, forming no similar arrangement in agarose. Sporadically, an elevated light background was observed. It was obviously due to impurities and could be eliminated by a further purification of the examined material in most cases. Simplicity and speed are important features of EPA. The average interval between thawing of samples and reading of results was 2.5 hours. The rotavirus RNA extracted from the examined samples, was stored at room temperature without any marked decrease of nucleic acid concentration for two months. Fourteen $\%$ of the originally positive samples became negative after 6 months of storage.

\section{Identification of bovine rotavirus by EPA, ELISA and CIEOP}

The results of comparative examinations of the feces samples collected from scouring calves by the three methods are summarized in Table 1 . Identical results by all three methods were obtained from $48(51 \%)$ of the 94 examined samples. EPA, ELISA and CIEOP yielded 43, 43 and 29 positive results, respectively. Results of combinations of two methods agreed in 89,3\% (89/94) in Group I (ELISA + EPA), in $82.9 \%$ (78/94) in Group II (CIEOP + EPA) and in $80.8 \%$ (76/94) in Group III (ELISA + CIEOP). Comparisons of the results obtained 


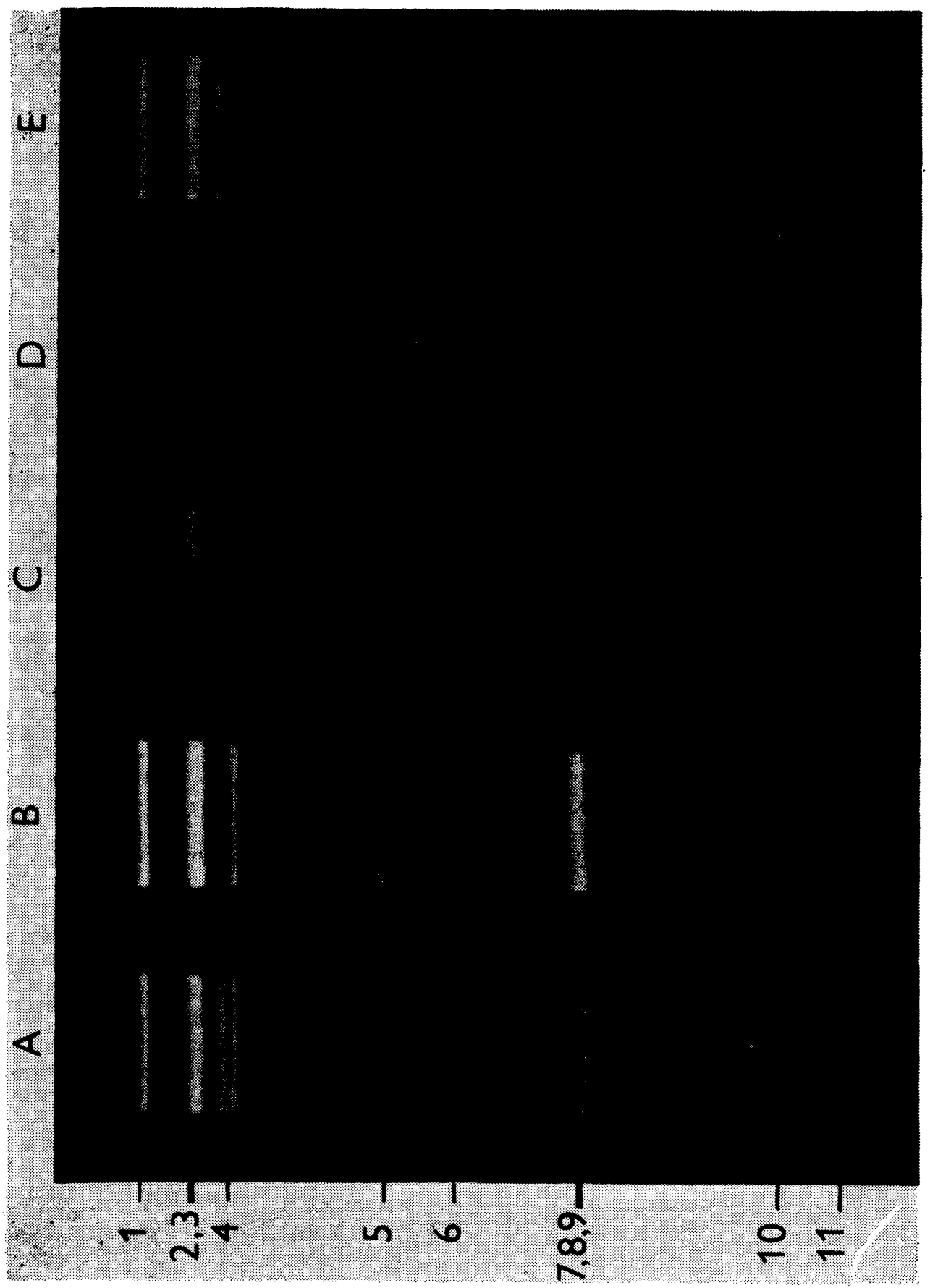

Fig. 2. Electrophoresis of RNA, extracted from bovine rotavirus isolates grown in cell cultures MA-104 or MDBK.

Bands $A, E=$ strain $B R-408$, band $B=$ strain $T M-224$, band $G=$ strain $T M-207$, band $D=$ reference strain Lincoln.

1 through $11=$ segment numbers 
Table 1

Comparison of results of examinations of 94 feces samples for the presence of bovine rotavirus, obtained by EPA, ELISA and CIEOP

\begin{tabular}{|l|c|c|c|}
\hline \multicolumn{1}{|c|}{ Pairs of methods } & Identical results & Controversial results & Total \\
\hline I. & ELISA +; EFA + 38 & ELISA +; EFA - 5 & \\
Total & ELISA -; EFA - 46 & ELISA - EFA + 5 & 94 \\
II. & CIEOP +; EFA + 28 & CIEOP +; EFA - 1 & \\
Total & CIEOP -; EFA - 50 & CIOOP -; EFA + 15 & 16 \\
III. & ELISA +; CIEOP + 27 & ELISA +; CIEOP - 16 & 94 \\
Total & ELISA -; CIEOP - 49 & ELISA -; CIEOP + 2 & \\
& & & 94 \\
\hline
\end{tabular}

$+1-$ positive, or negative result of respective method

by individual methods revealed differences in their relative sensitivities. While EPA and ELISA were positive in $96 \%(28 / 29)$ and $93 \%(27 / 29)$ of the CIEOP-positive samples, the relative sensitivity of CIEOP was only $65 \%(29 / 43)$ and $62 \%$ (27/43), when compared with EPA and ELISA, respectively.

The sensitivity of the rotavirus genome demonstration by EPA was equal to that of ELISA ( $88 \%, 38 / 43)$, although controversial results were obtained in 10 cases. However, higher numbers of controversial results were obtained from the comparison of EPA and CIEOP (16), or ELISA and CIEOP (18).

\section{Discussion}

Horizontal electrophoresis of the rotavirus genome in agarose, immunoenzymatic analysis and counter-immuno-electroosmophoresis were used for the identification of rotavirus in 94 feces samples collected from scouring calves in 6 rearing premises. Although all three methods detected the bovine rotavirus, they differed in sensitivity and specificity. The most reliable results were obtained by electrophoresis of the extracted RNA in agarose, allowing a direct identification of rotaviruses, based on the characteristic arrangement of the RNA segments in the gel and on evaluation of respective electrophoretogrammes. Rotavirus was demonstrated in 43 of the examined 94 feces samples by this method. Moreover, comparative evaluations of the electrophoretogrammes allow to analyse positive results in the epidemiological context and in time sequence (Fijtman et al. 1987), thus increasing the diagnostic value of EPA. Similarly as PAGE, EPA can be used for the differentiation of the rotavirus RNA not only within a single animal species, but also between various species (Rodger et al. 1979). On the other hand, in the form described here, EPA cannot be used for the differential diagnosis of further enteropathogenic viruses that may cause diarrhoea in calves either alone, or in combination of rotaviruses, such as bovine coronavirus, calicivirus, astrovirus, etc. The necessity to consider further enteropathogenic viruses in the aetiological diagnosis of calf scours is stressed by the fact that, in our experiments, rotavirus could not be detected by any of the methods used in $49 \%$ of the diarrhoeic calves under study.

While Kalica et al. (1978) described 11 segments resulting from PAGE of the rotavirus RNA, in our experiments only 8 and in one case 9 bands were dis- 
cernible in $1.5 \%$ agarose. Basing on a closer analysis of our electrophoretogrammes and on data published by other authors, we presume that this reduction of the number of bands is due to the positions of the segments 2 and 3, and 7,8 and 9, which are so close in agarose that the segments become indiscernible. Despite this reduction, we were able to demonstrate a certain number of variants of distribution of the rotavirus genome segments, extracted both from feces of scouring calves and from virus suspensions cultured in vitro (Fig. 1 and 2). The most marked migration speed deviations were seen in the genome of the strains BR-408, TM-207 and TM-123, showing a slower migration of the 11th segment, thus forming the "shortened RNA electropherotype", which has been described for the bovine rotavirus by $\mathrm{Paul}$ et al. (1988). A closer analysis, using more effective methods of molecular biology and serological and biological comparisons with other rotavirus isolates and reference strains, will be necessary for the investigations of possible associations between changes of bovine rotavirus genome and serological properties.

The examinations of feces samples showed a good agreement of results and equal sensitivities of ELISA and EPA. A similar agreement in the identification of rotaviruses has been reported for PAGE, ELISA and electron microscopy by other authors (Edwards et al. 1987). The fact than not only complete virions, but also their morphological protein subunits may be demonstrated in clinical samples by ELISA and CIEOP (Dea et al. 1980; Ellens et al. 1977) could explain the controversial results of the type "ELISA-positive, CIEOP-positive, EPA-negative". Although polyclonal antibodies to the inner bovine rotavirus capsid were used in ELISA and CIEOP (Franz et al. 1984), controversial results of the type "ELISA-positive, EPA-negative" require further analysis to demonstrate the possible existence of another serological group of bovine rotavirus, even if no deviation from the "long RNA electropherotype", typical for the Group A rotaviruses (Kalica et al. 1978) was observed in genome extracted from respective samples.

The major advantages of EPA are the straightforward procedure, involving no complicated sample processing and preparation of specific immune sera, and its speed, both making this method usable in routine investigations.

\section{Rychlá diagnostika bovinního rotaviru pomocí elektroforézy v agarózovém gelu}

$\mathbf{K}$ detekci rotavirů ve fécés průjmujících telat byly využity a navzájem porovnávány tři diagnostické techniky: horizontální elektroforéza genomu rotaviru $\mathrm{v}$ agaróze (EFA), nepřímá imunoenzymatická metoda (ELISA) a protisměrová imunoelektroosmoforéza (CIEOP). Jejich prostřednictvím bylo vyšetřeno celkem 94 vzorků fécés odebraných od průjmujících telat ze 6 různých chovi̊. Rotavirus byl detekován všemi diagnostickými testy celkem ve 48 vzorcích $(51 \%)$. Nejvíce pozitivních výsledkủ bylo získáno metodami ELISA a EFA (43\%), nejménè metodou CIEOP (29\%). Metoda EFA se citlivostí detekce rotavirového genomu vyrovnala nepřímému testu ELISA $(88 \%)$, kterým byl prokazován skupinově specifický rotavirový antigen. Obě metody svou citlivostí o $31 \%$ převyšovaly metodu CIEOP. Shoda ve výsledcích po vyhodnoceni jednotlivých diagnostických postupů byla mezi ELISA a EFA testy $89,3 \%$, mezi CIEOP a EFA testy $82,9 \%$ a mezi ELISA a CIEOP testy $80,8 \%$. 
EFA test poskytoval metodické výhody oproti oběma zbývajícím metodám a) jednoduchým provedením, které nevyžadovalo složitou preparaci výchozího materiálu ani připravu specifického hyperimunniho séra, b) rychlostí provedení, která dvojnásobně předčila nepřímý ELISA test a pétinásobně CIEOP test. $\mathrm{Na}$ víc možnost vzájemného posouzení elektroforetogramů zvýšila diagnostickou hodnotu EFA testu, protože pozitivita vyšetřovaných vzorkủ mohla být analyzována $\mathrm{v}$ epidemiologických souvislostech $\mathrm{v}$ časovém sledu.

\section{Скорая диагностика бычьего ротавируса с помощью электрофореза в агарозовом геле}

Для выявления ротавируса в пометах телят с поносом применяли и сравнивали 3 диагностических методов: горизонтальный электрофорез генома ротавируса в агарозе (ЭФА), непрямый метод иммүноферментного анализа (ЭЛИСА) и иммуноэлектроосмофорез в противоположном направлении (ЦИЕОП). Применением этих методов исследовали 94 пробы помета от телят с поносом происходящих из 6 хозяйств. Ротавирус обнаружили всеми диагностическими методами вообще в 48 пробах $(51 \%)$. Самое большое количество положительных результатов извлекали методами ЭЛИСА и ЭФА (43), методом ЦИЕОП только 29. Метод ЭФА по чүвствительности обнаружения ротавирусного генома может сравниться с непрямым методом ЭЛИСА $(88 \%)$, с помощью которого выявляли группово специфический ротавирусный антиген. Оба метода по чувствительности превышали меTод ЦИЕОП о $31 \%$. Совпадение результатов после оценки отдельных диагностических методов было между ЭЛИСА и ЭФА тестами 89,3\%, межАУ ЦИЕОП и ЭФА тестами $82,9 \%$ и межАУ ЭЛИСА и ЦИЕОП тестами $80,8 \%$.

Метод ЭФА предоставлял методические выгоды в сравнении с Аругими методами: а) простое исполнение, не требующее сложного препарирования исходного материала и подготовки специфической гипериммунной сыворотки, б) скоростью исполнения, два раза перевышавшего непнямый метод ЭЛИСА и пять раз метод ЦИЕОП. Вдобавок возможность взаимообсуждения электрофоретограммов повысила диагностическую ценность ЭФА - теста, так как положительность исследованных проб могли анализировать в эпидемиологической взаимосвязи во временной последовательности.

\section{Acknowledgements}

The authors wish to thank Dr. Svoboda and Dr. Kubíček for their valuable advice concerning methodology, and Mrs. Trnečková for the careful photographic documentation of results.

\section{References}

BISHOP, F. R.-DAVIDSON, G. P.-HOLMES, I. H. et al.: Virus particles in epithelial cells of duodenal mucosa from children with acute non-bacterial enteritis. Lancet, 1983: 1281 to 1283

BIDWELL, D. E.-BARTLETT, A.-VOLLER, A.: Enzyme immunoassays for viral diseases. J. infect. Dis., 136, 1977: 274-278 
BRIDGER, J. C. - WOODE, G. N.: Neonatal calf diarrhea: Identification of a reovirus-like (rotavirus) agent in faeces by immunofluorescence and immuno electron microscopy. $\mathrm{Br}$. vet. J., 131, 1975: 528-535

CLARKE, I. N.-Mc GRAE, M. A.: A rapid and sensitive method for analysing the genome profiles of field isolates of rotavirus. J. Virol. Meth., 2, 1981

CHUDZIO, T.-KASATMA, S.-IRVINE, N. et al.: Rapid screening test for the diagnosis of rotavirus infection. J. clin. Microbiol., 27, 1989: 2 394-2 396

DEA, S.-ROY, R. S.-BEGIN, M. E.: Counterimmunoelectroosmophoresis for detection of calf diarrhea coronavirus: Methodology and comparison with electron microscopy. J. clin. Microbiol., 10, 1980: 240-244

EDWARDS, S.-CHASEY, D.-NAPTHINE, P.-BANKS, C.: A comparison of three rapid diagnostic methods for the detection of rotavirus infections in calves. Vet. Microbiol., 13, 1987: $19-25$

ELLENS, D. J. - LEEUW, P. X.: Enzyme-linked immunosorbent assay for diagnosis of rotavirus infections in calves. J. Clin. Microbiol., 6, 1977: 530-532

FIJTMAN, N. L.-BARRANDEGUY, M. E.-CORNAGLIA, E. M. et al.: Variations and persistency of electrophoretypes of bovine rotavirus field isolates. Arch. Virol., 96, 1987: 275 to 182

FRANZ, J. - STTĚPANEK, J. - MENŠ́K, J. - PŠIKAL, I. - SVOBODA, I. - VALÍČEK, L. SMfD, B.: Detekce rotaviru v trusu telat imunoenzymatickým testem (ELISA). Veterinářství, 14, 1984: $22-24$

KALICA, A. R. - WYATT, R. G.-KAPIKIAN, A. Z.: Detection of differences among human and animal rotaviruses, using analysis of viral RNA. JAVMA, 173, 1978: 531

Mc NLLTY, M. S.-Mc FERRAN, J. B.-BRYSON, D. G.-LOGAN, E. F.-CURRAN, W. L.: Rotavirus infections. Vet. Rec., 99, 1976: 363.

MEBUS, C. A.-UNDERDAHL, N. R.-RHODES, M. B.-TWIEHAUS, M. J.: Calf diarrhea (scours): Reproduced with a virus from a field outbreak. Univ. Nebr. Res. Bull., 233, 1969: 2-16.

MEBUS, C. A.: Infections enteric viruses of neonatal animals. J. clin. Nutr., 30, 1977: $1851-1857$

MIDDLETON, P. J.-PETRIC, C. M.-HEWITT, M. T.-SZYMANSKI, M. T.-TAM, J. S.: Counter-immunoelectroosmophoresis for the detection of infantile gastroenteritis (ORBI-Group) antigen and antibody. J. clin. Path., 29, 1976: 191-197.

PAUL, P. S. - LYOO, Y. S. - WOODE, G. N. et al.: Isolation of a bovine rotavirus with a "super-short" RNA electrophoretic pattern from a calf with diarrhea. J. clin. Microbiol., 26, 1988: $2139-2143$

PEDLEY, S.-BRIDGER, J. C. et al.: Molecular characterization of rotavirus with distinct group antigens. J. General Virol., 64, 1983: 2 093-2 101

RODGER, S. M.-HOLMES, I. H.: Comparison of the genomes simian, bovine and human rotaviruses by gel electrophoresis and detection of genomic variation among bovine isolates. J. Virol., 30, 1970: 839-846

SANEKATA, T. - YOSHIDA, Y.-OKADA, H.: Detection of rotavirus in faeces by latex agglutination. J. Immun. Meth., 41, 1981: 377-385

SARKINEN, H. K.-TUOKKO, H.-HOLONEN, P. E.: Comparison of enzyme-immunoassay and radioimmunoassay for detection of human rotaviruses and adenoviruses from stool specimens. J. virol. Meth., 1, 1980: 331-341

ZYSSIS, G.-LAMBERT, J. P.-DE KEGEL, F.: Routine diagnosis of human rotaviruses in stools. J. clin. Path., 38, 1978: 175-178 